\title{
Comment
}

\section{Appellate Body Ruling in China-Publications and Audiovisual Products}

\author{
FRIEDER ROESSLER * \\ Executive Director, Advisory Centre on WTO Law
}

I would like to add to the analyses of the authors comments on two questions: First, how should measures falling under the GATT be distinguished from those falling under the GATS ? Second, could a measure inconsistent with one WTO agreement be justified by an exception contained in another?

\section{How should measures falling under the GATT be distinguished from those falling under the GATS?}

The Appellate Body concluded in China-Publications and Audiovisual Products that "where the content of a film is carried by physical delivery materials, [the Chinese restriction] will inevitably regulate who may import goods for the plain reason that the content of a film is expressed through, and embedded in, a physical good'. ${ }^{1}$ For the Appellate Body, this effect on goods (i.e., the physical film reel that crosses the border) is 'inevitable, rather than "incidental"' and 'the mere fact that the import transaction involving hard-copy cinematographic films may not be the "essential feature" of the exploitation of the relevant film does not preclude the application of China's trading rights commitments to the Film Regulation'. ${ }^{2}$

The authors ask whether the Appellate Body will 'automatically find a good whenever it sees tangible material? Is, for example, a paper lottery ticket automatically a good - so that cross-border restrictions on lottery activities affect trade in goods? - or merely an element in the supply of (lottery) services, making the entire activity subject only to GATS?' They further ask whether it suffices 'for a

*Email: roessler@acwl.ch. The views expressed are those of the author and should not be attributed to the ACWL.

1 Appellate Body Report, China-Measures Affecting Trading Rights and Distribution Services for Certain Publications and Audiovisual Entertainment Products, WT/DS363/AB/R, adopted 19 January 2010 ('China-Publications and Audiovisual Products'), para. 188.

2 Ibid., para. 196. 
traded product to be intangible for that product to be regarded only as a service? For example, if US film producers would stop physically shipping film reels or master copies to China for reproduction within China, and rather send the material electronically over the Internet, would that automatically imply that we can no longer talk of trade in goods and trading rights, and must examine the transaction exclusively under GATS (say, as a cross-border supply of 'entertainment services')? ... Should the law follow economic reality ... or should the law stick to physics (tangible is GATT, intangible is GATS)?'

I would like to add to the authors' analysis of these issues some general observations on the criteria that, in my view, should be used to determine whether a measure falls under the GATT or the GATS.

A product is a tangible object, a service an observable action. Put simply, what is regulated by the GATT can be touched, what is covered by the GATS can only be observed. Given the ease with which products and services can normally be distinguished, GATT and WTO jurisprudence and decision making have had no difficulty segregating the two, even though neither the GATT nor the GATS provides a definition of the terms 'product' and 'service'. The only case that gave rise to debate was the case of electricity because it is not clear whether electricity is a physical object. In practice, electricity has been treated as a product, presumably because the rules governing trade in products can easily be extended to electricity. ${ }^{3}$

While it is generally easy to distinguish between products and services, it can be very difficult to determine whether a measure applies to products or services or both. To take an example used by the authors: it is clear that a lottery ticket is a product and a lottery a service, but it may be very difficult to determine whether a specific measure regulates lottery tickets or lotteries or both. The legally relevant question is therefore not: 'Is a lottery ticket a good?' but: 'Does the measure at issue regulate lottery tickets ?' The national-treatment provision of Article III:4 of the GATT applies to internal regulations 'affecting' the sale of products. Article I of the GATS provides that the GATS applies to measures 'affecting' trade in services. Thus, the key term that the judicial organs of the WTO must interpret when deciding whether internal regulations fall under the GATT or the GATS is the term 'affecting'.

The ordinary meaning of the verb 'to affect' is 'to make a difference to'. Theoretically, there are three different methods of determining whether a measure 'makes a difference to' trade in goods or trade in services:

- First, one could look at the policy objective that the government pursues through the measure: Is it the government's intention to regulate trade in goods or trade in services?

3 For an extensive discussion on the properties of electricity, see the WTO Secretariat paper, 'Energy Services' (S/C/W/52), 9 September 1998. 
- Second, one could look at the effects in the economy brought about by the measure: Is the economic impact of the measure predominantly in the field of goods or in the field of services?

- And, third, one could look at the measure itself: Does the measure, explicitly or by necessary implication, regulate trade in goods or trade in services?

The first method would concentrate on what preceded the adoption of the measure (the legislature's intent); the second on what followed the adoption of the measure (the economic impact of the legislative action); the third on the measure itself (the regulatory scope of the measure).

In my view, a reliance on the policy objective for the purpose of determining the legal status of a measure under the basic provisions of the GATT and the GATS would be incompatible with the legal structure of these agreements. The basic provisions of these agreements prohibit measures with defined characteristics (e.g., customs duties exceeding the bound rate, restrictions, limitations on the number of service suppliers, etc.). They do not make distinctions between measures serving different policy purposes. For instance: a high charge on importation falls under the provisions of Article II of the GATT governing import charges but not under Article XI of the GATT governing import prohibitions, even if the charge was imposed with the objective of eliminating all imports and had the effect of discouraging all imports. Or: a production subsidy accorded to domestic breweries is, in principle, permitted under the GATT, while an exemption from sales tax for beer produced by domestic breweries violates the national-treatment requirement of Article III:4 of the GATT, even though the two measures are likely to have the same policy objective.

While the basic provisions of the GATT and the GATS do not distinguish between measures serving different policy purposes, many of the exceptions set out in these agreements permit measures that serve a defined policy purpose (e.g., 'to protect human health', 'to safeguard the external financial position'). The judicial organs of the WTO will normally examine the measure at issue in the light of such an exception only if the defendant has invoked it and, in doing so, declared which policy purpose its measure serves. The judicial organ's task is then limited to determining whether the measure has the characteristics, and was taken in the circumstances, described in the exception invoked. To take an example: if an import restriction inconsistent with Article XI:1 of the GATT protects both the imposing Member's domestic industries and its balance-of-payments, the complainant need not demonstrate which of these two purposes the measure served. Rather, it is the defendant that would have to invoke an exception justifying the restriction (for instance, the provisions permitting balance-of-payments measures) and to demonstrate that the measure complies with the conditions of that exception.

Under the basic legal scheme of the GATT and the GATS, therefore, the thorny question of the policy purpose of the measure at issue normally does not arise. This 
has the advantage that the complainant's claims and the rulings of the judicial organs can generally be limited to tangible facts: the characteristics of the measure at issue and the circumstances in which it was applied. That advantage would be lost if one were to define measures 'affecting' products or services as measures intended to affect goods or services. Every dispute under these agreements could then be resolved only after the intent behind the measure at issue had been ascertained. As a result, the complainants' and the judicial organs' tasks would be greatly complicated, and the normative force of the GATT and the GATS would be weakened.

If the intent behind a measure should not be used to determine the categorization of a measure under the GATT or the GATS, should one focus instead on the economic impact of the measure?

Most of the measures that fall under the GATT have an impact on the supply of services. Thus, a restriction on the importation of a product is bound to have an impact on the supply of distribution services. And most services cannot be supplied without goods - transportation services require vehicles, communication services electronic equipment. Consequently, if 'affecting' were interpreted to mean 'having an economic impact', the GATT and the GATS would simultaneously apply in almost all instances. The carefully negotiated differences between the legal regime governing trade in goods and that governing trade in services would be lost.

The economic impact of a law, regulation, or requirement generally depends on the market's reaction to it, which, in turn, depends on the decisions of private actors. The WTO can hold its Members responsible only for the laws, regulations, and requirements they adopt, not for the reactions of private actors to those measures. Consequently, the categorization of a measure under these agreements cannot appropriately depend on something that WTO Members do not control. Moreover, it is always extremely difficult and frequently impossible to segregate the market impact of a governmental measure from the market impact of other factors. Usually, this can be done only by observing the market over a period of time. If the economic impact of a measure were to determine its categorization under the GATT and GATS, therefore, a complaint against the measure could not be brought immediately upon its adoption, but only after the impact of the measure on the market could be determined. For this reason also, the 'having an economic impact' definition would be unworkable.

What then should 'affecting' mean?

I believe that the definition of this term must be in harmony with the basic function of the GATT and the GATS. These agreements do not oblige Members to pursue specific policy objectives; nor do they oblige Members to attain specific results in the marketplace. GATT and WTO panels and the Appellate Body have therefore consistently interpreted the basic provisions of the GATT and the GATS as norms setting out the conditions of competition that Members must create for actual and potential trade, and not as norms prescribing goals or 
results. ${ }^{4}$ A definition of 'affecting' that would be in harmony with the basic function of the GATT and the GATS would therefore be 'modifying conditions of competition in respect of'. With that definition, the interpreter facing the question of whether a measure falls under the GATT or the GATS would examine the distinctions made in the law, regulation, or requirement at issue and the necessary consequences of those distinctions.

In China-Publications and Audiovisual Products, the Appellate Body followed this approach. It examined whether the Chinese law at issue regulates the importation of a product or the supply of a service. The Appellate Body thus focused on the distinction made in the Chinese law, rather than on the policy objective of the Chinese government or the impact that the Chinese government sought to achieve through the law. For the reasons outlined above, I believe that there is no alternative to the approach adopted by the Appellate Body.

The authors ask whether 'the law' should 'follow economic reality' or 'stick to physics'. This implies that the judicial organs of the WTO should determine the scope of the market-access obligations under the GATT and the GATS in the light of prevailing economic realities. As the drafters of these agreements decided - for very good reasons - to 'stick to physics' in delineating the scope of obligations under these agreements, the judicial organs have no option but to do the same. If economic realities are such that a tariff concession for a product (e.g., hard-copy cinematographic films) is only meaningful when there is also a specific commitment on the cross-border supply of a service (for instance, entertainment services supplied by electronic means), the negotiators can add to the GATT concessions on products corresponding GATS commitments. If the negotiators failed to do so, the judicial organs of the WTO cannot step in and correct the omission without going beyond their mandate.

\section{Could a measure inconsistent with one WTO agreement be justified by an exception contained in another?}

Under the GATT, WTO Members may establish import and export monopolies and reserve the right to trade to state-owned enterprises. This follows from Article II:4, the note to Article XI, Article XVII, and Article XX(d) of the GATT. These provisions attempt to ensure that the GATT provisions applicable to private trading are not circumvented through state trading operations, but they do not curtail the right to establish import and export monopolies and other state trading enterprises. Moreover, under Article XX(d) of the GATT, Members may take all measures necessary to secure compliance with their laws and

4 For a recent confirmation of this jurisprudence see: Appellate Body Report, Brazil-Measures Affecting Imports of Retreaded Tyres, WT/DS332/AB/R, adopted 17 December 2007, para. 229 and footnote 437 . 
regulations relating to the enforcement of monopolies operated under Articles II and XVII.

In paragraph 5.1 of its Protocol of Accession, China assumed the obligation to accord all enterprises in China the right to trade, with respect to all goods except those listed in an Annex to the Protocol. Paragraph 5.1 defines the right to trade as the right to import and export goods. Unlike the other Members of the WTO, therefore, China may not establish monopolies on the importation of a product and enterprises with 'exclusive or special privileges' of the kind referred to in Articles II:4 and XVII:1 of the GATT with respect to the goods not listed in the Annex to the Protocol.

Paragraph 5.1 contains an introductory phrase, which states that China's trading-rights obligation is 'without prejudice to China's right to regulate trade in a manner consistent with the WTO Agreement'. The Appellate Body interpreted this phrase in its examination of a regulatory regime adopted by China under which films and other audiovisual products could be imported only by specified state enterprises charged with the review of their content. This regime restricted both what may be imported (audiovisual products with a certain content) and who may import (the specified state enterprises). The regime could thus be viewed to consist of:

- a measure that regulates trade within the meaning of the introductory phrase of paragraph 5.1 of the Protocol, namely the restriction on the importation of audiovisual products with a proscribed content, and

- a measure that denies trading rights guaranteed under the main clause of the first sentence of paragraph 5.1 of the Accession Protocol, namely the requirement that certain audiovisual products be imported exclusively by specified state enterprises.

The United States did not pursue any claim under the GATT in respect of the restriction on the importation of products subject to content review. The United States did, however, claim that China's failure to accord all enterprises in China the right to import audiovisual products was inconsistent with its obligation to provide the right to trade under the first sentence of paragraph 5.1 of the Protocol. China responded that its right to regulate trade consistently with the WTO Agreement, which it explicitly reserved under the introductory phrase, included the right to deny trading rights to protect public morals under Article XX(a) of the GATT.

The Panel and the Appellate Body thus faced a most curious situation: China invoked as a justification for a restriction on trading rights an exception to an agreement that it was not found to have violated. Was that legally possible? The Panel had avoided the issue by assuming arguendo that China could invoke Article $\mathrm{XX}(\mathrm{a})$ of the GATT and then finding that the denial of trading rights was not 'necessary' to protect morals and therefore did not meet the conditions of this exception. The Appellate Body, however, considered it appropriate to rule on the 
issue even though it, too, ultimately concluded that the denial of trading rights was not 'necessary to protect public morals' within the meaning of Article XX(a).

China's argument implies that the phrase 'without prejudice to China's right to regulate trade in a manner consistent with the WTO Agreement' entitles China to invoke in respect of its trading-rights commitment a GATT exception that applies to trade regulations. This is, however, not what this phrase states. Put simply: it does not say that China may deny trading rights consistently with the GATT; it says that the trading-rights commitment does not extend to WTO-consistent trade regulations.

The phrase was added to China's trading-rights commitment to take into account that, in fact, virtually every import or export regulation limits the number or types of enterprises that can exercise their right to trade. For instance, if a WTO Member accords shares in a tariff-rate quota to traders in accordance with their historical trade shares, it will limit the range of enterprises that are in a position to trade. A regulation that permits the importation of a dangerous chemical only by enterprises that meet certain safety standards would have the same effect. If a Member imposes a ban on the importation and production of meat with hormones, all enterprises are denied the possibility to import and export that product. In all these cases, the affected enterprises still have the right to trade, but cannot exercise that right because they do not meet the conditions set out in a trade regulation. In other words, in all these cases the regulations do not restrict the right to trade of particular enterprises (as envisaged in the main clause of the first sentence of paragraph 5.1), but impose conditions that all enterprises must observe in exercising their right to trade (as envisaged in the introductory phrase).

The paragraph 5.1 thus invites the interpreter to distinguish measures regulating trade from measures restricting the right to trade. By making that distinction, the interpreter ensures that China's right to regulate trade is not undermined by its additional commitment to provide the right to trade. Thus, if China takes a measure regulating trade that has the effect of narrowing the range of enterprises that can import or export, that effect should not, by itself, be considered to constitute a denial of the right to trade. Instead, it should be treated as an incidental consequence of the exercise of the right to regulate trade. Only direct limitations on the right to import or export are covered by China's trading-rights commitment, such as the grant of the exclusive right to import or export to a designated monopoly, state-owned enterprises, or enterprises owned by nationals. In my view, the threshold question before the Appellate Body was therefore whether the US claim concerned a measure regulating trade within the meaning of the introductory phrase (in respect of which the United States would have to make a claim under the GATT, and China could subsequently invoke Article XX of the GATT) or a measure restricting trading rights (in which case China could invoke only the exceptions from its trading-rights commitment set out in the Protocol).

Would that approach deprive China of the policy space accorded to other WTO Members under Article XX? I do not think so. Article XX lists nine policy areas in 
which WTO Members may, under specified conditions, take measures inconsistent with their obligations under other provisions of the GATT. These are public morals; human, animal, or plant life or health; importation or exportation of gold and silver; products of prison labour; national treasures of artistic, historic, or archaeological value; exhaustible natural resources; commodity agreements; stabilization of the price of domestic materials; and products in short supply. WTO Members do not pursue any of the policy goals listed in Article XX through denials of trading rights but through trade regulations. If a Member wishes to prevent the importation of plants carrying diseases, it must prohibit the importation of all such plants by all enterprises. It is not sufficient to exclude some enterprises. If a Member wishes to ensure that dangerous chemicals are imported only by enterprises capable of meeting certain safety standards, it will normally adopt a trade regulation imposing those safety standards on all importers. It is neither necessary nor efficient to deny to a category of enterprises the opportunity to meet those standards and thereby restrict their right to trade.

In practice, governments often deny the right to import and export to all but state-controlled enterprises in order to regulate the domestic prices of basic agricultural products and to improve their bargaining position in international markets for such products. State trading also occurs when governments take control of enterprises importing or exporting products of strategic importance. These and the other common reasons for denying trading rights are not mentioned in Article XX. It must be kept in mind that this provision is not a list of the most important societal values of the Members of the WTO. It lists those areas in which policy goals unrelated to trade cannot be achieved without imposing import or export restrictions, measures discriminating against imported products or products destined for export, or other measures inconsistent with the basic provisions of the GATT. The denial of trading rights as such is not inconsistent with the basic provisions of the GATT. There was therefore no reason for the drafters of the GATT to extend the scope of Article XX to the policy goals that governments pursue through the denial of trading rights.

The interpretative approach outlined above would thus not deprive China of the policy space accorded to all Members of the WTO under Article XX, because the policy goals listed in Article XX cannot be achieved through the denial of trading rights, and the policy goals that governments commonly seek to realize by reserving the right to trade to state trading enterprises and trade monopolies are not mentioned in Article XX.

At one stage in its analysis, the Appellate Body appears to lean towards the approach advocated here. It notes that the China Accession Working Party Report specifies that 'foreign enterprises and individuals with trading rights ha[ve] to comply with all WTO-consistent requirements related to importing and exporting, such as those concerning import licensing, TBT and SPS ${ }^{5}$ The Appellate Body 
read this as a confirmation that 'China's obligation to grant the right to trade cannot impair China's power to impose WTO-consistent import licensing, TBT, and SPS measures'. ${ }^{6}$ In its subsequent reasoning, however, the Appellate Body took a different approach. It found that 'the regulation of who may import and export specific goods will normally be objectively related to, and will often form part of, the regulation of trade in those goods'. 'When such a link exists', the Appellate Body concluded, 'then China may seek to show that, because its measure complies with the conditions of a GATT 1994 exception, the measure represents an exercise of China's power to regulate trade in a manner consistent with the WTO Agreement ... ${ }^{7} \mathrm{On}$ the basis of this reasoning, it permitted China to invoke Article $\mathrm{XX}(\mathrm{a})$ of the GATT to justify a measure inconsistent with its trading-rights commitment.

According to the Appellate Body, China can thus invoke Article XX of the GATT in respect of the denial of trading rights if three conditions are met:

- the measure must regulate 'those who may engage in the import and export of goods',

- it must be 'objectively related to ... the regulation of trade in those goods', and

- it must 'form part of, the regulation of trade in those goods'.

The criteria established by the Appellate Body cannot be found in the text of paragraph 5.1, in prior GATT or WTO jurisprudence, or in any principle of law. The wording of the introductory phrase clearly safeguards China's right to regulate trade in goods consistently with WTO law notwithstanding its trading-rights commitment. However, it does not make China's trading-rights commitment subject to its rights under the GATT. Since the provisions of the GATT permit China to channel trade through state-owned enterprises and trade monopolies, China's additional commitment to provide trading rights serves no purpose if its rights under the GATT delineate the scope of that commitment. The Appellate Body's ruling therefore gives a meaning to the introductory sentence that renders China's trading-rights commitment redundant.

WTO law makes numerous legal distinctions between measures that are in practice 'objectively' linked, for instance between measures affecting goods and those affecting services, between exchange restrictions and trade restrictions, and between foreign-investment regulations and foreign-trade regulations. However, there is no previous Panel or Appellate Body ruling that applied the rules governing one type of measure to another type of measure governed by other rules solely on the ground that the two types of measures were 'objectively' linked.

The Appellate Body suggests the contrary by referring to previous GATT and WTO cases ' where measures that did not directly regulate goods, or the importation

6 Ibid.

7 Ibid., para. 230.

8 Ibid. 
of goods, have nonetheless been found to contravene GATT obligations. Thus, for example, restrictions imposed on investors, wholesalers, and manufacturers, as well as on points of sale and ports of entry, have been found to be inconsistent with Article III:4 or Article XI:1 of the GATT 1947 or 1994. ${ }^{9}$ However, in none of these cases did the Panel or the Appellate Body rule that, by virtue of the close 'objective' link between the disputed measure and another policy area, the rules applicable in that other policy area could be invoked by the respondent. For instance, the GATT Panel that examined measures discriminating against imported products adopted by Canada under its foreign-investment law clearly distinguished between the trade measures and the investment measures adopted by Canada in the context of this law. It did not rule that Canada could impose a trade measure inconsistent with the GATT by virtue of the right to regulate investments that it had retained under the GATT. The cases cited by the Appellate Body do not support but undermine its conclusion because they demonstrate that the nationaltreatment obligation of the GATT, and its general prohibition of quantitative restriction, apply in all areas of policy making and that WTO Members cannot escape their GATT obligations by taking trade measures in the context of regulations extending to non-trade matters.

There is also no previous Panel or Appellate Body ruling in which the fact that the measure at issue forms part of a domestic regulation extending to other measures was considered to be legally relevant. In all previous cases, Panels and the Appellate Body avoided attributing legal relevance to an aspect of the measure at issue that is open to manipulation by Members. Thus, the Appellate Body ruled in China-Auto Parts that, in determining whether a charge is a 'border charge' falling under Article II of the GATT or an internal charge falling under the national-treatment provisions of Article III of the GATT, ' a degree of caution must be exercised in attributing decisive weight to characteristics that fall exclusively within the control of WTO Members, "because otherwise Members could determine by themselves which of the provisions would apply to their charges" ". ${ }^{10}$ Whether two measures are taken under a single or under two separate regulations falls exclusively within the control of WTO Members. The sound principle of GATT and WTO jurisprudence reflected in the ruling in China-Auto Parts was not applied in the present case.

In support of its 'objective link' criterion, the Appellate Body points out that the types of WTO-consistent requirements that China may impose according to the Working Party Report on China's Accession 'are not limited to requirements that apply directly to goods themselves, nor to requirements that apply to the activity of importing or exporting'.11 The Appellate Body states that '[i]mport licensing

9 Ibid., para. 227.

10 Appellate Body Report, China - Measures Affecting Imports of Automobile Parts (WT/DS339/AB/ R, WT/DS340/AB/R, WT/DS342/AB/R), adopted 12 January 2009, para. 178, quoting in part the Panel.

11 Appellate Body Report, China-Publications and Audiovisual Products, para. 225. 
requirements, for example, are requirements relating to the activity of importing goods. Typically, licensing requirements and their attendant procedures apply to and are satisfied by those who wish to import the goods, rather than by the goods themselves. ${ }^{12}$ It is difficult to see how these considerations support the conclusion that China's obligations regarding the right to import are qualified by its rights under the GATT. All laws are addressed to persons and all requirements must be fulfilled by persons, not objects or actions and hence not goods or services. A law regulating trade and a law restricting the right to trade, therefore, necessarily have the same addressee, namely persons engaged in the activity of trading. What distinguishes these laws is that the former regulates what may be imported (and may therefore fall under the GATT or one of the agreements supplementing the GATT) and the latter regulates who may import (and may therefore fall under paragraph 5.1). Only the content of the measures, not their addressees, can be relevant to their legal status under WTO law.

The Appellate Body argues that the introductory clause of paragraph 5.1 cannot be interpreted in a way that would allow a complainant to deny China access to a defence merely by asserting a claim under paragraph 5.1 and by refraining from asserting a claim under other provisions of the covered agreements relating to trade in goods that apply to the same or closely linked measures, and which set out obligations that are closely linked to China's trading rights commitments' ${ }^{13}$

The statement implies that the measure at issue in this dispute - the measure on which the Appellate Body had to rule - was China's regulatory regime for the importation of audiovisual products as a whole. However, in a WTO disputesettlement proceeding the measure at issue is defined by the complainant. Only the facts on which it bases its legal claim and the provisions it invokes in support can therefore be the basis of a ruling against the defendant. In this case, the United States did not base its claim on that part of China's regulatory regime that restricts what may be traded and that might therefore be inconsistent with the GATT, and there was consequently no need for China to invoke the defence of Article XX of the GATT. The United States, by basing its claim on that part of China's regulatory regime that restricts who may trade and on its rights under the Protocol of Accession rather than those under the GATT, therefore did not deny China access to a defence under the GATT. The Appellate Body's argument is essentially a petitio principii: It is intended to demonstrate that China has the right to invoke Article XX of the GATT as defence against a claim not based on the GATT, but in fact presupposes that this is so. The objective-link criterion possibly reflects a concern that in taking measures to regulate trade, Members may need to restrict simultaneously the right to trade and that it would be inappropriate to deny China the right to invoke Article XX of the GATT in such situations. However, as discussed above, while trade regulations, such as import-licensing, TBT, and SPS 
regulations, may narrow the range of enterprises that can in fact exercise their right to trade, they do not restrict the right to trade as such. The introductory phrase to paragraph 5.1 makes clear that such regulations must not be treated as denials of trading rights even if in practice not all enterprises are able to meet the requirements imposed by such regulations. If trade restrictions are clearly distinguished from restrictions on trading rights and China's trading-rights commitment is properly interpreted not to extend to the incidental impact of trade restrictions, there is no need to qualify China's trading-rights obligation by its rights under Article XX of the GATT and to develop a novel theory justifying that qualification. ${ }^{14}$ Put differently: the need to develop a tool to extract trade regulations covered by Article XX from the box 'trading rights' only arises if one has incorrectly put such trade regulations into that box in the first place.

Just as the authors and others, ${ }^{15}$ I have for these reasons difficulties fathoming the legal basis, the practical need, and the policy rationale of the objective-link principle. The Appellate Body takes pains to emphasize that its ruling is based on the introductory phrase in paragraph 5.1 of China's Protocol of Accession and that it applies only 'in this case'. However, while its ruling is of course case-specific, the reasoning underlying that ruling is not. The Appellate Body reasoned that links made by Members in their laws between 'objectively' linked measures can determine the scope of their obligations. That new principle puts the legal relationships between the various WTO agreements on an entirely new footing.

The agreements annexed to the WTO Agreement were negotiated separately as self-contained regimes. ${ }^{16}$ Where the drafters intended the obligations under one of these agreements to be qualified by rights under another legal instrument, they made that explicit. Under the new principle of WTO law posited by the Appellate Body, the relationships between these WTO agreements are no longer determined solely by the expressed intentions of the drafters; 'objective' and regulatory linkages between the measure at issue and another measure subject to other rules under another agreement become relevant. This raises legal issues such as the following: Could the provisions on regional trade agreements of Article XXIV of the GATT now be invoked to justify measures inconsistent with WTO agreements that

14 This is not to say that the distinction between trade regulations and trading-rights limitations can easily be made in all cases. However, the difficulty of making that distinction does not exceed the difficulty of distinguishing for example between internal regulations and restrictions on importation (Articles III:4 and XI:1 of the GATT), between standards for services and market-access limitations on the supply of services (Articles VI:5 and XVI:2 of the GATS), or between measures prohibiting the sale of a product and those prescribing product characteristics (Article III:4 of the GATT and Annex 1, paragraph 1, of the TBT Agreement).

15 Fernando Piérola (2010), 'The Availability of a GATT Article XX Defence with Respect to a NonGATT Claim: Changing the Rules of the Game?', Global Trade and Customs Journal, 5: 172-175.

16 Some of these agreements were taken over from the GATT era, during which they operated as independent agreements concluded among different GATT contracting parties with separate disputesettlement procedures. The decision to incorporate these agreements into the WTO Agreement was taken only in the final stages of the Uruguay Round. Only then were the acceptance procedures set out in the drafts of each of these agreements replaced by a single acceptance procedure in the WTO Agreement. 
do not permit discrimination in favour of regional trading partners, such as the SPS, TBT, and TRIPS agreements? Could Article XX of the GATT now be invoked to justify export subsidies inconsistent with the Subsidies Agreement even though that Agreement contains an exhaustive list of exceptions to the prohibition of export subsidies? Can the rights that the Members of the WTO have retained under the GATS be invoked to justify trade measures inconsistent with the GATT ? Can Members, by creating 'objective' and regulatory links between policy measures covered by different WTO agreements, now manipulate the scope of their obligations under these agreements? In the past, the answer to all these questions was clearly negative; now we no longer know.

The dispute could easily have been settled without a ruling on the relationship between Article XX and China's trading-rights commitment. The Panel did so; the Appellate Body could have followed its example. The new theory developed by the Appellate Body does not provide China with additional policy space because the denial of trading rights is not a policy instrument with which any of the policy goals mentioned in Article XX can effectively be implemented. Perhaps future jurisprudence will reveal why the Appellate Body justified an unnecessary ruling with no impact on the respondent's policy options on the basis of a new principle that casts a shadow of uncertainty over the whole of WTO law. 